\title{
APPLICATION OF QUICK ON THE DRAW MODEL TO IMPROVE EXPOSITORY WRITING SKILLS FOR FIFTH GRADE STUDENTS OF SDN 2 KARANGPOH IN ACADEMIC YEAR OF 2020/2021
}

\author{
Rifqi Aulia Rahman', Suhartono², Tri Saptuti Susiani ${ }^{3}$ \\ Universitas Sebelas Maret \\ arahman.rifqi323@student.uns.ac.id
}

\section{Article History}

accepted 30/8/2021

approved 30/9/2021

published 30/10/2021

\begin{abstract}
The objectives of the study were: (1) to describe the application of Quick on the Draw model to improve expository writing skills; (2) to improve expository writing skills through the application of Quick on the Draw model; (3) to describe the obstacle and solution in implementing the Quick on the Draw model to improve expository writing skills. This collaborative classroom action research was conducted in three cycles. The subjects were the teacher and students of fifth grade of SDN 2 Karangpoh. The data were qualitative and quantitative data. Data collection techniques used observation, interviews, and tests. The data validity used triangulation of techniques and triangulation of sources. The data analysis included data reduction, data presentation, and conclusions drawing. The results showed that: (1) the steps of the Quick on the Draw model were: (a) delivering learning objectives, (b) preparing question cards, (c) creating group formation and learning material, (d) delivering rules of game, (e) having problem solving, ( $f$ ) delivering results of discussion, ( $g$ ) giving rewards, and ( $h$ ) reviewing exam questions; (2) the application of the Quick on the Draw model improved expository writing skills; (3) the obstacle was the students focused on answering questions quickly but did not pay attention to the accuracy of the answers. The solution was the teacher guided the students to answer questions quickly and accurately.
\end{abstract}

Keywords: quick on the draw model, expository writing skills

\begin{abstract}
Abstrak: Penerapan Model Quick on The Draw untuk Meningkatkan Keterampilan Menulis Eksposisi Siswa Kelas V SDN 2 Karangpoh Tahun Ajaran 2020/2021. Tujuan penelitian ini yaitu: (1) mendeskripsikan penerapan model Quick on The Draw untuk meningkatkan keterampilan menulis eksposisi; (2) meningkatkan keterampilan menulis eksposisi melalui penerapan model Quick on The Draw; (3) mendeskripsikan kendala dan solusi penerapan model Quick on The Draw dalam meningkatkan keterampilan menulis eksposisi. Penelitian tindakan kelas ini dilaksanakan dalam tiga siklus. Subjek penelitian ialah guru dan siswa kelas V SDN 2 Karangpoh. Data yang digunakan berupa data kualitatif dan kuantitatif. Teknik pengumpulan data menggunakan observasi, wawancara, dan tes. Validitas data menggunakan triangulasi teknik dan sumber. Analisis data dilaksanakan melalui reduksi data, penyajian data, dan penarikan kesimpulan. Hasil penelitian menunjukkan bahwa: (1) langkah penerapan model Quick on The Draw, yaitu: (a) penyampaian tujuan pembelajaran, (b) persiapan kartu soal, (c) pembentukan kelompok dan belajar materi, (d) penyampaian aturan permainan, (e) penyelesaian soal, (f) penyampaian hasil diskusi, (g) pemberian penghargaan, (h) pembahasan jawaban secara klasikal; (2) penerapan model Quick on The Draw dapat meningkatkan keterampilan menulis eksposis siswa kelas V SDN 2 Karangpoh tahun ajaran 2020/2021; (3) kendala dalam penelitian adalah siswa berfokus pada kecepatan dan kurang memperhatikan ketepatan jawaban, adapun solusi dari kendala tersebut yaitu guru membimbing siswa agar menyelesaikan soal secara cepat dan tepat.

Kata Kunci: model quick on the draw, keterampilan menulis eksposisi
\end{abstract}




\section{PENDAHULUAN}

Pembelajaran Bahasa Indonesia di sekolah dasar berkaitan dengan empat keterampilan berbahasa, yaitu: keterampilan menyimak (listening skills), keterampilan berbicara (speaking skills), keterampilan membaca (reading skills), dan keterampilan menulis (writting skills), Keempat keterampilan ini saling berkaitan satu sama lainnya (Susanto, 2016: 241). Menulis adalah kegiatan komunikasi yang ditandai dengan penyampaian pesan secara tertulis kepada orang lain menggunakan media berupa media tulis (Dalman, 2016: 3). Menulis dapat menumbuhkan keaktifan siswa dalam pembelajaran serta dapat meningkatkan daya pikir serta kreativitasnya. Kegiatan menulis dalam sekolah dasar dibagi menjadi dua tahapan, yaitu menulis permulaan dan menulis lanjut. Menulis permulaan adalah kegiatan menulis yang dilakukan di kelas rendah berupa cara menulis dasar seperti memegang alat tulis sampai dapat menghasilkan suatu kalimat. Menulis lanjut adalah kegiatan menulis yang dilakukan di kelas tinggi berupa menulis kalimat sesuai gambar, menulis paragraf sederhana, menulis karangan pendek, dan menulis eksposisi. Samsudin (2012: 3) menyatakan eksposisi merupakan jenis karangan yang berusaha menerangkan atau menjelaskan pokok pikiran yang dapat memperluas pengetahuan pembaca.

Keberhasilan pembelajaran Bahasa Indonesia dalam meningkatkan keterampilan menulis ditentukan oleh faktor guru serta faktor siswa pada saat kegiatan pembelajaran. Guru memiliki peran untuk menyampaikan materi yang akan diajarkan pada siswa agar pengetahuan akan materi tersebut bertambah. Selain peran, guru dalam mencapai tujuan pembelajaran perlu menggunakan strategi, model, metode, dan media pembelajaran. Dengan demikian, guru dituntut untuk kreatif serta inovatif dalam menciptakan pembelajaran dengan menggunakan model untuk mengaktifan siswa.

Berdasarkan hasil wawancara dengan guru kelas V SDN 2 Karangpoh pada hari Sabtu, 29 Agustus 2020, didapatkan informasi bahwa (1) siswa dalam hal menulis masih kurang khusunya dalam membuat kalimat serta menghubungkannya; (2) antusias siswa tergolong kurang apabila diberi tugas untuk menulis oleh guru dikarenakan belum maksimalnya penerapan model pembelajaran serta pembelajaran yang masih berpusat pada guru. Hal tersebut tentunya akan mempengaruhi keterampilan siswa dalam menulis eksposisi, dll.

Dari uraian di atas, alternatif pemecahan masalah yang dianggap sesuai untuk mengatasi permasalahan tersebut adalah diperlukan model pembelajaran yang sesuai untuk mendukung keterampilan serta pemahaman siswa. Salah satu model yang dapat mengatasi masalah tersebut ialah model pembelajaran kooperatif tipe Quick On The Draw. Model pembelajaran Quick on The Draw sendiri dirancang untuk melakukan aktivitas berpikir, kemandirian, kesenangan, artikulasi, dan kecerdasan emosional melalui kegiatan kerja kelompok, membaca, bergerak, berbicara, menulis, mendengarkan, melihat dan kerja individu melalui suasana pertandingan untuk menyelesaikan soal secara cepat dan juga tepat. Sejalan dengan pendapat Susanti (2015: 62) yang menyatakan model Quick on The Draw dapat meningkatkan keaktifan dan semangat belajar karena diarahkan untuk berpikir, mandiri, dan dipadukan dengan aktivitas kerja kelompok, menyimak, bergerak, menulis, dan berbicara. Alasan mengapa menggunakan model Quick on The Draw sebagai alternatif pemecahan masalah tersebut karena model Quick on The Draw merupakan cara yang menarik dan mudah diterapkan, melibatkan aktivitas seluruh siswa yang mengandung unsur permainan dan penguatan (Ayu, Linda, dan Agustina, 2018: 33).

Berdasarkan latar belakang di atas maka peneliti tertarik untuk mengadakan penelitian tindakan kelas yang bertujuan untuk: (1) mendeskripsikan penerapan model Quick on The Draw untuk meningkatkan keterampilan menulis eksposisi pada siswa kelas V SDN 2 Karangpoh tahun ajaran 2020/2021; (2) meningkatkan keterampilan 
menulis eksposisi melalui penerapan model Quick on The Draw pada siswa kelas V SDN 2 Karangpoh tahun ajaran 2020/2021; (3) mendeskripsikan kendala dan solusi penerapan model Quick on The Draw dalam meningkatkan keterampilan menulis eksposisi siswa kelas V SDN 2 Karangpoh tahun ajaran 2020/2021.

\section{METODE}

Penelitian ini merupakan penelitian tindakan kelas yang dilaksanakan secara kolaboratif antara peneliti dengan guru kelas. Adapun prosedur penelitian ini menggunakan model penelitian tindakan kelas yang terdiri dari empat tahapan, yaitu: (1) perencanaan, (2) pelaksanaan, (3) observasi, dan (4) refleksi. Penelitian ini dilakukan dalam tiga siklus enam pertemuan. Subjek penelitian ini ialah guru dan siswa kelas V SDN 2 Karangpoh tahun ajaran 2020/2021 dengan jumlah 28 siswa yang terdiri dari 12 siswa laki-laki dan 16 siswa perempuan.

Data yang digunakan dalam penelitin ini yaitu data kualitatif berupa penerapan model Quick on The Draw dan data kuantitatif berupa data mengenai hasil keterampilan menulis siswa kelas V SD tentang eksposisi. Sumber data dalam penelitian ini yaitu siswa kelas V SDN 2 Karangpoh, guru kelas IV, dan dokumen. Adapun teknik pengumpulan data yang digunakan adalah observasi, wawancara, dan tes. Uji validitas data menggunakan triangulasi teknik dan sumber. Teknik analisis data yang digunakan dalam penelitian ini yaitu reduksi data, penyajian data, dan penarikan kesimpulan sesuai model analisis data menurut Miles dan Huberman (Sugiyono, 2011: 247-253).

Aspek yang diukur dalam indikator kinerja penelitian ini adalah pelaksanaan langkah-langkah model Quick on The Draw dan ketuntasan hasil keterampilan menulis tentang eksposisi setelah menerapkan model Quick on The Draw dengan persentase yang ditargetkan sebesar $85 \%$.

\section{HASIL DAN PEMBAHASAN}

Proses pembelajaran dilaksanakan dengan langkah-langkah: (1) penyampaian tujuan pembelajaran, (2) persiapan kartu soal, (3) penyampaian materi dan pembentukan kelompok, (4) penyampaian aturan permainan, (5) penyelesaian soal/permasalahan dan menuliskannya secara berkelompok, (6) penyampaian hasil diskusi kelompok, (7) pemberian penghargaan kelompok, (8) pembahasan jawaban secara klasikal. Langkah-langkah yang digunakan oleh peneliti mengacu pada langkah-langkah yang dikemukakan oleh Arifin, Wilujeng, dan Jumadi (2020: 122) dan Huriyanti \& Rosiyanti (2017: 69) kemudian peneliti menyimpulkan menjadi langkah yang telah disebutkan di atas. Hasil observasi model Quick on The Draw mengalami peningkatan pada setiap siklusnya hingga mencapai indikator kinerja penelitian yang ditargetkan sebesar $85 \%$.

Tabel 1. Persentase Hasil Observasi model Quick on The Draw terhadap g uru dan siswa

\begin{tabular}{lcccc}
\hline \multirow{2}{*}{ Sumber Data } & \multicolumn{3}{c}{ Siklus } \\
\cline { 3 - 5 } & & I & II & III \\
\hline Guru & Persentase (\%) & 67,97 & 80,47 & 91,15 \\
\hline Siswa & Persentase (\%) & 66,67 & 78,65 & 90,10 \\
\hline
\end{tabular}

Berdasarkan tabel 1, diketahui bahwa proses pembelajaran pada siklus I, II, dan III selalu meningkat. Peningkatan hasil pengamatan terhadap guru dari siklus I ke siklus II sebesar $12,50 \%$, dari siklus II ke siklus III mengalami peningkatan sebesar $10,68 \%$. Peningkatan hasil pengamatan terhadap siswa dari siklus I ke siklus II sebesar $11,98 \%$, dari siklus II ke siklus III mengalami peningkatan sebesar $11,45 \%$. 
Pada siklus III, baik guru dan siswa, hasil pengamatan sudah mencapai target yaitu $85 \%$.

Tabel 2. Analisis Hasil Tes Keterampilan Menulis Eksposisi pada Siklus I, II, dan III

\begin{tabular}{ccccc}
\hline No & Siklus & \multicolumn{3}{c}{ Tuntas (\%) } \\
\cline { 3 - 5 } & & Pertemuan I & Pertemuan II & Rata-rata \\
\hline 1 & I & 50,00 & 60,71 & 55,36 \\
2 & II & 71,43 & 78,57 & 75,00 \\
3 & III & 85,71 & 92,86 & 89,29 \\
\hline
\end{tabular}

Berdasarkan tabel 2, diketahui bahwa rata-rata ketuntasan hasil tes keterampilan menulis eksposisi setelah guru menerapkan model pembelajaran dengan model Quick on The Draw pada siklus I, II, dan III selalu meningkat. Peningkatan persentase siswa yang tuntas dari siklus I ke siklus II sebesar $19,64 \%$, dari siklus II ke siklus III sebesar $14,29 \%$. Rata-rata ketuntasan pada siklus III sebesar $89,29 \%$ sudah mencapai target indikator kinerja penelitian yaitu $85 \%$.

Model Quick on The Draw dapat meningkatkan keaktifan dan semanangat belajar siswa sehingga akan meningkatkan keterampilan menulis siswa. Data di atas membuktikan pendapat Susanti (2015: 62) menyatakan model Quick on The Draw dapat meningkatkan keaktifan dan semangat belajar siswa karena diarahkan untuk berpikir, mandiri, dan dipadukan dengan aktivitas kerja kelompok, menyimak, bergerak, menulis, dan berbicara. Dan didukung juga dengan pendapat Erihadiana \& Lismawati (2017: 29) beberapa keunggulan dari Model Quick on The Draw ialah (a) mendorong siswa kerja kelompok; (b) memberikan pengalaman mengenai bermacam keterampilan berbahasa yang didorong oleh kecepatan aktivitas, belajar mandiri, membaca dan menjawab pertanyaan dengan hati-hati dan tepat. Kemudian di dalam penelitian Marleni (2016: 151) mengemukakan bahwa siswa yang aktif dan semangat memiliki minat belajar yang tinggi. Minat belajar siswa yang tinggi akan berpengaruh terhadap keterampilan menulis siswa. Hal tersebut sesuai dengan pendapat Apriani (2017: 322) yang menyatakan minat belajar terbukti memiliki pengaruh yang signifikan terhadap kemampuan menulis karangan siswa. Menurut penjelasan tersebut model Quick on The Draw dapat meningkatkan keterampilan menulis siswa, seperti yang disebutkan dalam penelitian Karimah, Abidin \& Fuady (2019: 23) menyatakan model Kooperatif Quick on The Draw dapat meningkatkan keterampilan menulis siswa.

Alasan mengapa keterampilan menulis meningkat setelah diterapkan Model Quick on The Draw ialah (1) penyampaian tujuan pembelajaran diterapkan pada pembelajaran agar siswa lebih terarah, sesuai dengan pendapat Erayati, Thomas, dan Syahrudin (2014: 8) yang menyatakan kegiatan penyampaian tujuan pembelajaran akan membantu siswa agar pikiran siswa terarah dengan materi pelajaran yang akan dicapai dan siswa mempersiapkan diri untuk mengikuti proses pembelajaran; (2) persiapan kartu soal, tahap ini siswa diberi materi pelajaran secara singkat oleh guru, guru menjelaskan materi dengan jelas, menggunakan bahasa yang mudah dipahami dan sesuai dengan tujuan pembelajaran. Ketika guru menyampaikan materi pelajaran, guru menggunakan variasi dalam penyampaiannya dengan harapan siswa lebih tertarik dengan materi yang akan dipelajari. Hal ini sesuai dengan pendapat Artikawati (Aliffiani, Syafrina, dan Husin, 2018: 26) yang menyatakan bahwa variasi memberikan pengaruh positif pada perhatian dan keaktifan siswa, sejalan dengan pendapat Kurniasih, Sunarya, dan Panjaitan (2017: 1659) menyebutkan keaktifan siswa dapat meningkatkan keterampilan menulis siswa; (3) pembentukan kelompok dan belajar materi, dalam tahap ini guru memberikan instruksi kepada siswa untuk membentuk kelompok yang beranggotakan 5-6 anak. Pembentukkan kelompok akan melatih siswa 
dalam berinteraksi dan bekerjasama dengan temannya. Seperti yang dikemukakan oleh Hadi \& Noor (2013: 62) bahwa pembentukan kelompok dapat meningkatkan kemampuan bekerjasama, bersosialisasi, komunikasi, serta prestasi belajar siswa; (4) penyampaian aturan permainan, dalam tahap ini siswa dijelaskan oleh guru terkait aturan dan teknis permainan. Guru menjelaskan aturan permainan tidak hanya dengan lisan, melainkan dengan metode demonstrasi agar siswa lebih memahami tentang aturan permainan. Penggunaan metode demonstrasi pada langkah ini dapat melibatkan siswa secara aktif dan lebih memahami apa yang disampaikan guru (Safrinur, Margiati, dan Halidjah, 2014: 8). Kegiatan dilanjutkan dengan pembagian LKS ke setiap kelompok siswa; (5) penyelesaian soal, dalam tahap ini siswa diminta mengerjakan soal yang terdapat pada kartu secara diskusi dan bekerjasama, dengan berdiskusi dan bekerjasama dalam menyelesaikan, maka pembelajaran menjadi lebih efektif dan efisien. Seperti yang dikemukakan oleh Hapsari \& Yonata (2014: 183) dengan bekerjasama, siswa diharapkan mampu melakukan lebih banyak hal secara berkelompok dibandingkan bekerja secara individu, karena akan memudahkan siswa dalam menyelesaikan sebuah masalah; (6) penyampaian hasil diskusi, dalam hal ini setiap kelompok yang memenangkan permainan menunjuk perwakilan anggotanya untuk mempresentasikan hasil diskusinya. Kegiatan ini terlaksana dengan baik dimana siswa percaya diri untuk mempresentasikan hasilnya dan siswa yang lain diberikan motivasi agar siswa lebih mudah diarahkan, diberi penugasan, cenderung memiliki rasa ingin tahu yang besar, aktif dalam mengikuti pembelajaran, serta berani menyampaikan tanggapan (Sidik \& Sobandi, 2018: 191); (7) pemberian penghargaan diberikan kepada kelompok yang memenangkan permainan. Selain itu, siswa yang belum memenangkan permainan juga diberi motivasi oleh guru untuk lebih bersemangat serta bekerjasama di pertemuan selanjutnya agar memenangkan permainan. Hal ini sesuai dengan pendapat (Akmal \& Susanti, 2019: 164) yaitu pemberian penghargaan memiliki dampak positif yang menjadikan siswa lebih bersemangat, meningkatkan motivasi, serta mendorong siswa untuk mengikuti teladan siswa yang memperoleh penghargaan; (8) pembahasan jawaban secara klasikal. Pada kegiatan ini siswa diberikan motivasi serta menunjuk siswa untuk menyimpulkan hasil pembelajaran. Penunjukkan siswa ini dilakukan dengan maksud melatih rasa melaksanakan kewajiban siswa dan membuat siswa yang lain bersiap untuk memberikan jawabannya. Hal ini sejalan dengan pendapat Silberman (Jakfar, 2018: 105) yang menyatakan bahwa metode penunjukkan pembicara selanjutnya dapat meningkatkan partisipasi aktif siswa dalam pembelajaran. Berdasarkan keseluruhan yang telah dibahas, model Quick on The Draw efektif untuk meningkatkan keterampilan menulis eksposisi siswa.

Kendala Model Quick on The Draw dalam meningkatkan keterampilan menulis pada siswa kelas V SDN 2 Karangpoh tahun ajaran 2020/2021 yaitu: (1) siswa kurang tertarik dengan penjelasan materi; (2) siswa masih ribut saat diminta berkelompok; (3) siswa kurang paham dengan penjelasan aturan permainan; (4) siswa kurang memperhatikan ketepatan jawaban; (5) siswa kurang memperhatikan dan menanggapi presentasi; (6) siswa kurang berkontribusi saat menyimpulkan pembelajaran; (7) terdapat siswa yang tidak membaca materi; (8) terdapat siswa yang bergantung dengan anggota lain; (9) tanggapan yang diberikan siswa kurang sesuai dengan topik pembahasan; (10) siswa yang memberikan tanggapan kurang merata. Adapun solusi untuk mengatasi kendala di atas yaitu: (1) melakukan variasi dalam menyampaikan materi; (2) menentukan terlebih dahulu tempat kelompok; (3) menjelaskan aturan permainan dengan demonstrasi agar siswa lebih paham; (4) membimbing siswa agar menyelesaikan soal selain cepat, tetapi juga tepat; (5) memotivasi dan memberi penghargaan kepada siswa yang memberikan tanggapan; (6) memotivasi dan menunjuk siswa untuk menyimpulkan hasil pembelajaran; (7) membimbing dan memantau siswa agar semua siswa mempelajari materi; (8) memantau serta 
memberikan penegasan kepada semua siswa untuk aktif dalam kelompok; (9) mengarahkan siswa untuk memberikan tanggapan dengan baik; (10) memberi instruksi dan menunjuk siswa secara acak agar memberikan tanggapan.

\section{SIMPULAN}

Berdasarkan uraian di atas, dapat disimpulkan: (1) penerapan Quick on The Draw untuk meningkatkan keterampilan menulis eksposisi siswa kelas V SDN 2 Karangpoh tahun ajaran 2020/2021 dilaksanakan dengan langkah-langkah: (a) penyampaian tujuan pembelajaran, (b) persiapan kartu soal, (c) penyampaian materi dan pembentukan kelompok, (d) penyampaian aturan permainan, (e) penyelesaian soal/permasalahan dan menuliskannya secara berkelompok, (f) penyampaian hasil diskusi kelompok, (g) pemberian penghargaan kelompok, (h) pembahasan jawaban secara klasikal; (2) model Quick on The Draw dapat meningkatkan keterampilan menulis eksposisi siswa kelas V SDN 2 Karangpoh tahun ajaran 2020/2021. Keterampilan menulis eksposisi siswa meningkat pada setiap siklusnya. Hal tersebut dapat dibuktikan dengan adanya peningkatan persentase ketuntasan siswa dari $55,36 \%$ pada siklus 1, pada siklus II meningkat menjadi $75 \%$, dan pada siklus III meningkat menjadi 89,29\%; (3) kendala penerapan model Quick on The Draw dalam meningkatkan keterampilan menulis eksposisi siswa kelas V SDN 2 Karangpoh salah satunya adalah siswa hanya fokus pada kecepatan dan kurang memperhatikan ketepatan jawaban, Adapun solusi dari kendala tersebut yaitu guru membimbing siswa agar menyelesaikan soal secara cepat dan tepat.

Berkaitan dengan hasil penelitian yang telah dicapai maka dapat disampaikan saran-saran sebagai berikut: (1) sebaiknya siswa lebih fokus dan aktif dalam pembelajaran sehingga dapat lebih mudah memahami materi yang disampaikan. Siswa lebih berani dan percaya diri dalam bertanya, menjawab pertanyaan dan memberikan tanggapan; (2) sebaiknya guru dapat mengoptimalkan penerapan model Quick on The Draw yang dapat dijadikan sebagai referensi dalam memilih model pembelajaran sehingga siswa dalam pembelajaran menjadi lebih aktif dan percaya diri serta mendapatkan pembelajaran yang lebih bermakna; (3) sekolah sebaiknya mendukung guru dalam penerapan model dan media pembelajaran yang menarik dengan melengkapi sarana dan prasarana guna meningkatkan kualitas pembelajaran.

\section{DAFTAR PUSTAKA}

Akmal. S. \& Susanti, E. (2019). Analisis Dampak Penggunaan Reward dalam Pembelajaran Pendidikan Agama Islam di SMA Muhammadiyah Aceh Singkil. Jurnal IImiah DIDAKTIKA, 19 (2), 159-177.

Aliffiani, H.S., Syafrina, A., \& Husin, M. (2018). Kemampuan Guru dalam Menerapkan Keterampilan Variasi Stimulus di SD Negeri 71 Banda Aceh. Jurnal IImiah Pendidikan Guru Sekolah Dasar, 3 (2), 24-34.

Apriani, H. (2017). Pengaruh Minat Belajar Terhadap Kemampuan Menulis Karangan Narasi pada Siswa. Jurnal DEIKSIS, 9 (3), 316-322.

Arifin, I., Wilujeng, I., \& Jumadi. (2020) The Effect of Quick on The Draw Model Assisted by The Physics Learning Book Integrated Pancasila Values on Critical Thinking Skill. JPPPD (Jurnal Penelitian dan Pengembangan Pendidikan Fisika), $6(1), 121-130$. 
Ayu, Y.E., Linda, R., \& Agustina. (2018). Penerapan Pembelajaran Quick on The Draw pada Materi Laju Reaksi untuk Meningkatkan Aktivitas Belajar Siswa. Jurnal Pendidikan Kimia Indonesia, 2 (1), 32-41.

Dalman. (2016). Keterampilan Menulis. Jakarta: Raja Grafindo Persada

Erayati, T., Thomas, Y., \& Syahrudin, H. (2014). Pelaksanaan Kegiatan Belajar Mengajar oleh Guru pada Mata Pelajaran Ekonomi Kelas XI IPS 1 di SMA. Jurnal Pendidikan Ekonomi, 2 (1), 1-12.

Erihadiana, M. \& Lismawati, W. (2017). Penerapan Model Quick On The Draw dengan Menggunakan Media Permainan Bingo untuk Meningkatkan Keterampilan Berpikir Kreatif PAI Siswa. Islamic Religion Teaching and Learning Journal, 2 (1), 26-38.

Hadi, S.G. \& Noor, A.J. (2013). Keefektifan Kelompok Belajar Siswa Berdasarkan Sosiometri dalam Menyelesaikan Soal Cerita Matematika di SMP. Jurnal pendidikan Matematika, 1 (1), 60-67.

Hapsari, N.W. \& Yonata, B. (2014). Keterampilan Kerjasama saat Diskusi Kelompok Siswa Kelas XI IPA pada Materi Asam Basa Melalui Penerapan Model Pembelajaran Kooperatif di SMA Kemala Bhayangkari 1 Surabaya. Unesa Journal of Chemical Education, 3 (2), 181-188.

Huriyanti, L. \& Rosiyanti, H. (2017). Perbedaan Motivasi Belajar Matematika Siswa setelah Menggunakan Strategi Pembelajaran Quick On The Draw. FIBONACCI Jurnal Matematika dan Pendidikan Matematika, 3 (1), 65-75.

Jakfar, M. (2018). Upaya Meningkatkan Keaktifan Peserta Didik pada Pembelajaran Fikih melalui Model Market Place Activity di MAN 3 Kulon Progo. Jurnal Pendidikan Madrasah, 3 (1), 103-114.

Karimah, F.I., Abidin, Z., \& Fuady, A. (2019). Kemampuan Komunikasi Matematis Tulis Siswa Kelas VII pada Materi Perbandingan Melalui Model Pembelajaran Quick on The Draw. Jurnal P3, 14 (7), 22-27.

Kurniasih, S.M., Sunarya, D.T., \& Panjaitan, R.L. (2017). Upaya Meningkatkan Keterampilan Menulis melalui Metode Writing Procces pada Siswa Kelas IV SDN Sukasirna 1 Kecamatan Sumedang Selatan Kaupaten Sumedang. Jurnal Pena IImiah, 2 (1), 1651-1660.

Marleni, L. (2016). Faktor-faktor yang Mempengaruhi Minat Belajar Siswa Kelas VIII SMP Negeri 1 Bangkinang. Journal Cendekia: Jurnal Pendidikan Matematika 1 (1) 149-159.

Safrinur, K.Y., Margiati, \& Halidjah, S. (2014). Penggunaan Metode Demonstrasi untuk Meningkatkan Aktivitas dan Hasil Belajar dalam Pembelajaran IPA di Sekolah Dasar. Jurnal Pendidikan Sekolah Dasar, 7 (1), 1-9.

Samsudin, A. (2012). Peningkatan Kemampuan Menulis Eksposisi Berita dan Menulis Eksposisi llustrasi Siswa Kelas V Melalui Model Pembelajaran Kooperatif Terpadu Membaca dan Menulis. Jurnal Penelitian Pendidikan, 13 (2), 1-11.

Sidik, Z. \& Sobandi, A. (2018). Upaya Meningkatkan Motivasi Belajar Siswa Melalui Kemampuan Komunikasi Interpersonal Guru. Jurnal Pendidikan Manajemen Perkantoran, 3 (2), 190-198.

Sugiyono. (2016) Metode Penelitian Kuantitatif, Kualitatif, dan $R \& D$. Bandung: Alfabeta

Susanti, Y. (2015). Peningkatan Kemampuan Mengidentifikasi Unsur Intrinsik Cerita Rakyat Menggunakan Model Quick on The Draw. Jurnal Vox Edukasi, 6 (1), 5979.

Susanto, A. (2016). Teori Belajar dan Pembelajaran di SD. Jakarta: Prenadamedia Group. 